\title{
Ortaokul Öğrencilerinin Üstbilişsel Farkındalık Düzeyi İle Matematik Öz Yeterlik Algısının Matematik Başarısına Etkisi*
}

\author{
Büşra ÖZTÜRK¹, Aytaç KURTULUŞ² \\ ${ }^{1}$ Ögretmen-MEB, bsrozturk42@gmail.com \\ ${ }^{2}$ Doç. Dr. Eskişehir Osmangazi Üniversitesi, Eüitim Fakültesi, Matematik.ve Fen Bilimleri Eğitimi Bölümü, aytackurtulus@gmail.com
}

Geliş Tarihi/Received: 24.04.2017Ｋabul Tarihi/Accepted: 08.09.2017 e-Yayım/e-Printed: 30.10 .2017

DOI: http://dx.doi.org/10.14582/DUZGEF.1840

\begin{abstract}
ÖZ
$\mathrm{Bu}$ araştırma, ortaokul öğrencilerinin üstbilişsel farkındalık düzeyi ile matematik öz yeterlik algısının matematik başarısına etkisini belirlemek amacıyla yapılmıştır. Bu araştırmada nicel araştırma yöntemlerinden ilişkisel tarama modeli kullanılmıştır. Araştırmanın örneklemini Konya ili Kadınhanı ilçesinde bulunan Milli Eğitim Bakanlığg'na bağlı dört devlet okulunda, 2015-2016 eğitim- öğretim yılı II. Dönemi’nde öğrenim gören 680 ortaokul öğrencisi oluşturmaktadır. Araştırmada veri toplama aracı olarak Üstbilişsel Farkındalık Envanteri (ÜFE) ve Matematik Öz Yeterlik Algısı Ölçeği kullanılmıştır. Elde edilen verilerin analizinde; Bağımsız Gruplar t testi, tek yönlü varyans analizi (ANOVA), Pearson Momentler Çarpımı Korelasyon analizi ve çoklu regresyon analizinden yararlanılmıştır. Araştırmanın bulgularına göre ortaokul öğrencilerinin üstbilişsel farkındalık düzeyinin cinsiyete, sınıf düzeyine ve matematik karne notu değişkenine göre anlamlı farklılaştığı; matematik öz yeterlik algısının sınıf düzeyi ve matematik karne notuna göre farklılaşırken cinsiyet değişkenine göre farklılaşmadığı görülmüştür. Üstbilişsel farkındalık düzeyi ve matematik öz yeterlik algısının matematik başarısını \%47 oranında açıkladığı ve matematik başarısı üzerinde anlamlı etkiye sahip oldukları görülmüştür.
\end{abstract}

Anahtar Kelimeler: Ortaokul, üstbilişsel farkındalık, öz yeterlik, matematik öz yeterlik algısı, matematik başarısı.

\section{The Analysis Of The Effect Of Metacognitive Awareness And Mathematics Self-Efficacy Perceptions On Mathematics Achievement Of Middle School Students}

\begin{abstract}
The purpose of the study is to investigate the effect on the maths achievement of the metacognitive awareness level and mathematic self- efficacy perception of secondary school students. Relational screening model was used as a qualitative search method in this study. The sample of the study were composed of 680 secondary school students of 2015-2016 academic year from four different state schools in Kadınhanı, Konya. As a data collection tool in research was gathered by using the Metacognitive Awareness Inventory (MCI) and Mathematics Self-efficacy Perception Scale. In the analysis of the obtained data; Independent Groups $t$ test, one way variance analysis (ANOVA), Pearson Moments Multiplication Correlation analysis and multiple regression analysis were used. According to the findings of the study, the metacognitive awareness level of middle school students differed significantly according to gender, grade and mathematic success; It was seen that the mathematics self-efficacy perception varied according to grade level and mathematics grade score and did not differ according to gender. Metacognitive awareness level and mathematics selfefficacy perceived mathematical success by $47 \%$ and found significant effects on mathematical success.
\end{abstract}

Keywords: Middle school, metacognitive awareness, self-efficacy, mathematics self-efficacy, mathematics achievement.

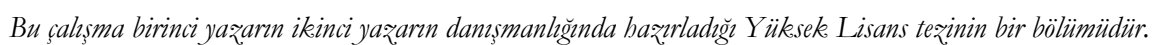




\section{GİRİŞ}

Uzun yıllardır eğitim alanında benimsenen davranışçı kuram öğrencilere pasif bilgi alıcısı rolü yüklerken, yapılan önemli değişikliklerle eğitim alanında önemli bir yer edinen yapılandırmacı kuram geleneksel anlayışları yıkarak, öğrencilere bilgi üzerinde aktif bir rol yüklemiştir. Yapılandırmacı anlayış, bilgiye ulaşmak için derinlemesine araştırmalar yapan, öğrendiği bilgiyi işlevsel hale getirebilen öğrenciler yetiştirebilmeyi amaçlamaktadır (Tüysüz, Karakuyu \& Bilgin, 2008). Yapılandırmacı öğrenme yaklaşımının geleneksel öğretim yaklaşımına göre önemli farklılıklarından birisi, insanın düşünme yeteneğine sahip olan bir varlık olduğu göz önüne alındığında, zihinsel süreçlerin ve zihinsel becerilerin öğretim sürecine dâhil edilmesidir. Yapılandırmacı öğrenme yaklaşımı, kişinin ön bilgilerinin yeni bilgilerle kaynaştırılmasını içerir. Ancak yeni öğrenilen kavramların içselleştirilmesi için kişinin kendi zihinsel süreçlerini işe koşması ve süreç boyunca davranışlarını kontrol etmesini kısaca kişinin kazandığı bilgiyi yapılandırması gerektiğini savunmaktadır.

Yapılandırmacılık, Piaget ve Vygotsky olmak üzere birçok öğrenme kuramcısının görüşleri doğrultusunda gelişme göstermiştir. Bilgi, bireyden ayrılmayan bir olgu olup, birey var olan ön bilgilerine dayalı olarak ve çevre ile etkileşime girerek kendisi aktif bir şekilde bilgiyi oluşturmaktadır. Öğrencilerin sahip oldukları bilgiyle yeni bilgiyi ilişkilendirmeleri, kendi öğrenme süreçlerini izlemeleri ve edindikleri yeni bilgileri farklı alanlarda kullanarak bilgiyi kendine ait kılmaları ancak nasıl öğrendiklerinin farkında olmalarıly gerçekleşecektir. Bu açıdan yapılandırmacı öğrenme kuramını tamamlayan kuramlardan biri de üstbiliştir (Akt. Tüysüz, Karakuyu \& Bilgin, 2008).

Flavell üstbilişi "kişinin kendi bilişsel süreçleri hakkındaki bilgisi ve bu bilginin bilişsel süreçleri kontrol etmek için kullanılması" olarak tanımlamışır (Akt. Namlu, 2004, s:125). Ancak buna ek olarak birçok araştırmacı verilen tanımı rehber edinip daha açıklayıcı tanımlamalar yapmaya çalısmış fakat kesin çizgili tanımlardan kaçınmışlardır. Üstbilişe farklı açılardan bakarak, boyutlara ayırmaya çalışmış ve bu boyutları tanımlama yoluna gitmişlerdir. Bu nedenle üstbiliş hakkında birçok tanıma ulaşmak mümkündür. Esas olarak üstbiliş, bireyin düşünme ve öğrenme sürecini yönetebilmesi ve öğrenme sürecinde neyi bilip bilmediğinin farkında olması olarak tanımlanabilir. Örneğin, herhangi bir problemi düşünürken öğrencinin, hangi stratejileri bildiğini, hangilerinin işe yarayacağını kısacası tüm alternatifleri göz önünde bulundurma kaygısı içinde olması bir üstbiliş etkinliğidir (Candan, 2005).

Ülkemizde üstbiliş kavramı literatüre değişik ifadelerle kazandırılmıştır. Üstbiliş kavramını Türk bilim alan yazınına; Senemoğlu (1998) yürütücü biliş, Namlu (2004), Yurdakul (2004), Ekenel (2005) ve Akyol (2009) biliş ötesi, Özsoy (2006), Çakıroğlu (2007a) ve Yıldız (2008) üstbiliş, Olgun (2006), Duru (2007) ve Yabaş (2008) biliş üstü ve Gelen (2003) bilişsel farkındalık olarak aktarmışlardır. Bu araştırmada ise metacognition sözcüğü üstbiliş olarak aktarılmıştır. Üstbiliş tanımlandıktan sonra, bu çatının altında araştırmacılar tarafından ortaya koyulan birçok terime ulaşmak mümkündür. Bu terimler, yapılan çalışmalarda üstbilişin farklı açılardan ele alınmasıyla oluşmuştur. Üstbilişsel farkındalık, üstbilişsel bilgi, üstbilişsel düzenleme, üstbiliş becerileri ve öz düzenleme stratejileri gibi çok çeşitlidir (Akt. Melanlıŏ̆lu, 2011).

Schraw ve Dennison (1994), üstbilişi bireyin düşünme, anlama ve kendi öğrenmesini kontrol etme yetisi olarak; bireyin başarısını arttırabilmesi için uyguladığ1 planlama, izleme, düzenleme ve daha iyi uygulama yeteneğini ise üstbilişsel farkındalık olarak tanımlar (Akt. Akçam, 2012).

$\mathrm{Bu}$ konu üzerinde çalışış birçok bilim adamı, üstbilişin iki temel boyuttan oluştuğu ortak fikrine sahiptirler. Üstbiliş "Bilişin Bilgisi" ve "Bilişin Düzenlenmesi" olarak iki ana boyuta ayrılmaktadır. Bilişin bilgisi açıklayıcı bilgi, yöntemsel bilgi ve durumsal bilgi alt boyutlarından oluşmaktadır (Demirsöz, 2010). Açıklayıcı bilgi, bireyin nasıl öğrendiğini ve öğrenmesini etkileyen faktörlere ilişkin bildiklerini içerir. Yöntemsel bilgi, öğrenme sürecini gerçekleştirirken hangi stratejinin kullanılması gerektiğini ve stratejinin nasıl uygulamaya geçirileceğini bilmesini gerektirir. Durumsal bilgi, bireyin bulunduğu duruma uygun hangi bilginin kullanılmasının gerekli olduğunu bilmesi yani duruma uygun gösterilmesi gereken davranışın ne olduğunu bilmesini gerektirir. Bilişin düzenlenmesi planlama, bilgi yönetimi, izleme, hata ayıklama ve değerlendirme alt boyutlarından oluşmaktadır (Demirsöz, 2010). Planlama, bireyin öğrenme sürecine uygun gerekli strateji ve kaynakları seçmesidir. Bilgi yönetimi, bilgiyi daha anlamlı ve işlevsel hale getirmek için kullanılan strateji ve 
becerilerdir. İzleme, bireyin kendi öğrenme sürecini ve süreç boyunca kullandiğ1 stratejileri kontrolden geçirmesidir. Hata ayıklama, bireyin öğrenme sürecinde bilgiyi anlamak ve ortaya çıkan ürün hatalarını düzeltmek için kullandığı düzenlemelerdir. Değerlendirme, bireyin öğrenme gerçekleştikten sonra elde edilen başarıyı ve kullandığı yolun etkililiğini analiz etmesidir (Akt. Demirsöz, 2010). Bireyin bilişin bilgisine ve bilişin düzenlenmesine sahip olması yeni bir bilgiyi içselleştirme sürecinde farkındalık sahibi yapacaktır. Yani kendi öğrenme sürecini kontrol edebilen, yönetebilen ve nasıl gerçekleștirdiğini fark edebilen birey haline gelecektir. Bu bağlamda üstbiliş ve üstbilişsel farkındalık kavramları önem arz etmektedir.

Üstbilişi ve üstbilişsel farkındalığı konu edinen çeşitli araştırmalarda üstbilişin, çocukların eğitiminde ve başarılarının artırılmasında önemli bir yeri bulunduğu ve eğitim-öğretim ile üstbilişsel farkındalık düzeyinin arttırılabileceği sonucuna ulaşılmıştır (Akçam, 2012; Ataalkın, 2012; Bağçeci, Döş \& Sarıca, 2011; Balcı, 2007; Baltac1, 2009; Çikrıkci \& Odac1, 2013; Demirsöz, 2010; Ekenel, 2005; Ektem, 2007; Gelen, 2003; Kaplan, Duran \& Baş, 2016; Karatay, 2010; Landine \& Stewart, 1998; Liliana \& Lavinia, 2011; Özsoy, 2007; Pilten \& Yener, 2010; Saraç, 2010; Topçu \& Tüzün, 2009; Tuncer, 2011; Yurdakul, 2004). Özellikle soyut işlemler dönemine geçiş yapan, ülkemizde ortaokul seviyesinde öğrenim gören öğrencilerin üstbilişsel farkındalıklarının hızla arttığı görülmektedir. Bu durum okullarda öğrencilerin çok yönlü gelişimi için farklı derslerde çeşitli öğretim programları uygulanmasına bağlanabilir. Özellikle yaşamımız boyunca her zaman karşımıza çıkan matematik dersinin üstbilişsel farkındalık ile ilişkisi yadsınamaz. Üstbilişsel farkındalık, öğrencilerin soyut olan matematik dersini anlayarak öğrenmelerinde ve öğrendiklerini içselleştirmede son derecede önemlidir. Çünkü üstbilişsel farkındalık sahibi öğrenciler üst düzey düşünür, sorgular, bilgiye kendisi ulaşır. Literatür incelendiğinde de matematik başarısı ile üstbilişsel farkındalığın ilişkili olduğuna dair birçok çalışma yer almaktadır (Balc1, 2007; Canca, 2005; Çelik, 2012; Ektem, 2007).

Ortaokul Matematik Öğretim Programı'nda matematik eğitimi kapsamında, bireylere kazandırılması amaçlanan alana özgü beceriler yer almaktadır. Bu beceriler, "Problem Çözme, Matematiksel Süres Becerileri, Duyussal Beceriler, Psikomotor Beceriler, Bilgi ve İletişim Teknolojileri” olarak ifade edilir (MEB, 2013). Bu bağlamda öğrencilerin bilişsel kazanımlarının, duyuşsal ve psikomotor alanlardaki kazanımlarla entegre edilmesi gerektiğinin dikkate alındığı görülmektedir. Bu durum bilişsel becerilere dayanan üstbilişsel farkındalı̆̆ın, programda yer alan diğer beceriler ile de desteklenerek öğrencilerin matematik başarısını artırmada etkili olabileceğini göstermektedir. Özellikle bilişsel becerilerin duyuşsal beceriler ile desteklenmesi, öğrencileri motive edecek ve kendilerinde var olan yetileri hakkında algılarını geliştirecektir. Buradan hareketle matematik başanısı üzerinde etkisi olduğu düşünülen ve kendine inanan bireyler haline gelmesinde etkili olan matematik Öz yeterlik algısı kavramı ortaya çıkmaktadır.

Matematik öz yeterlik algısı, bireyin matematikle ilgili performans sürecini başarı ile tamamlaması için kendi yeteneklerine dair algıları şeklinde tanımlanır (Ural, Umay \& Argün, 2008). Erdoğan, Baloğlu ve Kesici (2011)'ye göre öz yeterlik alg1sı, bireyin kendi kapasitesine yönelik inancıdır ve matematik dersinde başarı gösteren öğrencilerin matematik öz yeterlik algılarının yüksek olması beklenir.

Matematik öz yeterlik alg1sı, matematik performansının belirleyicilerindendir. Matematik öz yeterlik algısına dair yapılan birçok çalışma, matematik öz yeterlik algısının matematik başarısı ile ilişkili olduğunu göstermektedir (Alc1, 2007; Çelik, 2012; Çağlayan, 2010; Duran, 2011; Gülten \& Soytürk, 2013; Kitsantas, Cheema \& Ware, 2011; Öztürk \& Şahin, 2015; Pajares \& Miller, 1994; Reçber, 2011; Şengül \& Gülbağc1, 2013; Terzi \& Mirasyedioğlu, 2009). Matematik öz yeterlik alg1sı kavramı incelendiğinde öz yeterlik alg1s1 yüksek olan bireylerin matematiğe karşı kendine güvenlerinin tam olması, karmaşık problemlere karşı sakin ve mantıklı yaklaşmaları, sahip oldukları matematiksel becerilerin farkında olmaları, matematik söz konusu olduğunda cesaretli olmaları, başarılı olacağına inanmaları beklenir. Yüksek matematik öz yeterlik algısına sahip olan öğrenciler, ders sırasında konuyu öğrenmek için dikkatlerini daha çok yoğunlaştırmakta ve daha fazla zaman kullanmaktadırlar (Öztürk \& Şahin, 2015). Matematik öz yeterlik alg1sı düşük olan bireyler ise matematiğe karş1 çekingen bir tavır sergileyebilir, problemlerin çözümünde yetersiz olduklarını düşünebilirler, çözüme ulaşabilme konusunda şüpheli davranabilirler, kendine güvenleri düşük olabilir. Ülkemizdeki öğrencilerin matematik öz yeterlik algısını arttırma amacıyla, Ortaokul Matematik Öğretim Programı'nda öğrencilerin 
programda öngörülen öğrenme alanlarındaki yeterliklerinin, öz yeterlik algıları ve özgüven sahibi olmaları ile geliştirilmesi önerilmektedir (MEB, 2013).

Sonuç olarak alanyazın incelendiğinde üstbilişsel farkındalık düzeyi ve matematik öz yeterlik algısı kavramlarını bir araya getiren, ortaokul öğrencileri ile yapılan herhangi bir çalışmaya rastlanılmamıştır. Bireylerin üstbilişsel farkındalık düzeyi ile matematik öz yeterlik algısının matematik başarısının üzerinde etkisi olup olmadığı önemli bir araştırma konusudur. Diğer yandan bu araştırma matematik eğitimi alanında araştırma yapacak araştırmacılara yeni fikirler verebilir. Matematik eğitimi programının uygulayıcısı olan öğretmenlere de araştırma sonuçlarından hareketle öğrencilerin kendilerine olan algılarını ve üstbilişsel farkındalıklarını geliştirmelerine olanak tanıyacak uygun ortamlar sağlamaları konusunda yardımcı olabilir. Bu araştırmanın eğitimin kalitesinin artırılmasına yardımcı olabileceğine, öğretmenlere öğretim süreçlerini düzenlerken öğrencilerin üstbilişsel farkındalıklarını ve matematik öz yeterlik algılarını artırmanın neden gerekli olduğu konusunda yol göstereceğine inanılmaktadır.

Araştırmanın amac1, "ortaokul ögrencilerinin sahip olduğu üstbilissel farkendalık düzeyi ve matematik öz yeterlik algisımın matematik başarısına etkisi nedir?" sorusuna cevap aramaktır. Bu amaç doğrultusunda araştırmanın alt problemleri aşağıdaki şekilde oluşturulmuştur.

1) Öğrencilerin üstbilişsel farkındalık düzeyi cinsiyet, sınıf düzeyi ve matematik karne notu değişkenlerine göre farkl1l1k göstermekte midir?

2) Öğrencilerin matematik öz yeterlik alg1sı cinsiyet, sınıf düzeyi ve matematik karne notu değişkenlerine göre farkll1ık göstermekte midir?

3) Öğrencilerin üstbilişsel farkındalık düzeyi ile matematik başarısı arasında bir ilişki var mıdır?

4) Öğrencilerin matematik öz yeterlik algısı ile matematik başarısı arasında bir ilişki var mıdır?

5) Öğrencilerin üstbilişsel farkındalık düzeyi ile matematik öz yeterlik algısının matematik başarısına etkisi var midir?

\section{YÖNTEM}

Bu bölümde araştırmanın deseni, evren ve örneklem, veri toplama araçları, verilerin toplanması ve verilerin çözümlenmesi ile ilgili bilgilere yer verilmiştir.

\subsection{Araştırma Deseni}

$\mathrm{Bu}$ araştırmada nicel araştırma yöntemlerinden ilişkisel tarama yöntemi kullanılmıştır. Büyüköztürk, Çakmak, Akgün, Karadeniz ve Demirel (2011)'e göre tarama yöntemi ile yapılan araştırmalar, bir konu ile ilgili geniş kitlelerin görüşlerinin özelliklerini betimlemeyi hedefleyen araştırmalardır. Geniş kitlelere ulaşmak, verileri hazır cevap seçenekli ölçekler kullanarak elde etmek ve elde edilen verileri betimleyebilmek amaciyla bu araştırma yöntemi seçilmiştir.

\subsection{Evren ve Örneklem}

$\mathrm{Bu}$ araştırmanın evrenini Konya ilinde bulunan ortaokul öğrencileri oluştururken, örneklemini ise Konya ili Kadınhanı ilçesinde bulunan Milli Eğitim Bakanlığı'na bağlı dört devlet okulunda, 2015-2016 eğitim öğretim yllı II. döneminde öğrenim gören 680 ortaokul öğrencisi oluşturmaktadır. Bu örneklemin seçimindeki temel mantık okulların ilçe merkezindeki öğrenci sayısı bakımından fazla olan ortaokullardan olması, okulların çeşitli mahallerden öğrenci profiline sahip oluşudur. Araştırma örneklemi ise seçkili örneklem alma yollarından olan uygun örnekleme yoluyla tespit edilmiştir. Uygun örneklemede araştırmacı çalışması için elverişli bir şekilde ulaşabileceği grubu belirlemekte ve araştırma verilerini o gruptan toplamaktadır. Elverişli örnekleme ismi ile de bilinen bu örnekleme türünde amaç, zaman, para ve iş gücü faktörlerindeki kaybı en aza indirgemektir (Büyüköztürk vd., 2011).

Tablo 1'de araştırmanın örneklemini oluşturan öğrencilerin demografik özelliklerine ilişkin frekans (n) ve yüzde $(\%)$ değerleri sunulmuştur. 
Tablo 1. Örneklemin demografik bilgilerine ait frekans ve yüzde dağglımları

\begin{tabular}{|c|c|c|c|c|c|c|c|}
\hline \multicolumn{7}{|l|}{ Seçenekler } & \multirow[t]{2}{*}{ Toplam } \\
\hline & & Kiz & Erkek & & & & \\
\hline \multirow[t]{3}{*}{ Cinsiyet } & $\mathrm{n}$ & 361 & 319 & & & & 680 \\
\hline & $\%$ & 53.1 & 46.9 & & & & 100 \\
\hline & & 5 & 6 & 7 & 8 & & \\
\hline \multirow[t]{2}{*}{ Sinif } & $\mathrm{n}$ & 168 & 158 & 175 & 179 & & 680 \\
\hline & $\%$ & 24.7 & 23.2 & 25.7 & 26.3 & & 100 \\
\hline Matematik & & 1 & 2 & 3 & 4 & 5 & \\
\hline Karne & $\mathrm{n}$ & 43 & 95 & 151 & 155 & 236 & 680 \\
\hline Notu & $\%$ & 6.3 & 14 & 22.2 & 22.8 & 34.7 & 100 \\
\hline Sosyo- & & Düşük & Orta & İyi & Çok & & \\
\hline ekonomik & $\mathrm{n}$ & 246 & 341 & 79 & 14 & & 680 \\
\hline durum & $\%$ & 36.2 & 50.1 & 11.6 & 2.1 & & 100 \\
\hline
\end{tabular}

Tablo 1 incelendiğinde; araştırmaya katılan kı ve erkek öğrenci sayılarının homojen bir dağılım gösterdiği, öğrencilerin sınıf düzeylerine de homojen dağıldığ1 görülmektedir. Öğrencilerin matematik başarılarına bakıldığında karne notu bir ve iki olan öğrencilerin sayısının az olduğu, karne notu üç ve dört olan öğrencilerin sayısının birbirine yakın olduğu ve karne notu beş olan öğrencilerin sayısının diğer öğrencilere göre daha fazla olduğu fark edilmektedir. Ayrıca öğrencilerin sosyo- ekonomik düzeylerinin düşük ve orta seviyede yoğunlaştığı görülmektedir.

\subsection{Veri Toplama Araçları}

$\mathrm{Bu}$ araştırmada öğrencilerin üstbilişsel farkındalıklarını ölçmek amacıyla Schraw ve Dennison (1994) tarafindan geliştirilen (Metacognitive Awareness Inventory, MAI), Türkçe geçerlik ve güvenirlik çalışması Akın, Abacı ve Çetin (2007) tarafindan yapılan Üstbilişsel Farkındalık Envanteri (ÜFE) ve öğrencilerin matematik öz yeterlik alg1 düzeylerinin belirlenmesinde Umay (2001) tarafindan geliştirilen Matematik Öz Yeterlik Algısı Ölçeği” kullanılmıştır.

\subsection{1. Üstbilişsel farkındalık envanteri (ÜFE)}

Üstbilişsel Farkındalık Envanteri 52 maddeden oluşmaktadır. Beşli Likert tipinde hazırlanan envanterden en yüksek 260 puan, en düşük 52 puan alınabilir. Envanterde bulunan maddeler içerisinde olumsuz madde bulunmamaktadır. Üstbilişin iki ana boyutundan oluşan envanter, alt boyutlara da ayrılmaktadır. Birinci ana boyut olan Bilişin Bilgisi boyutuna ait 17 madde yer almaktadır. Bilişin Bilgisi boyutu üç alt boyuta ayrılmaktadır. Bu alt boyutlar “Açıklayıcı Bilgi”, "Yöntemsel Bilgi” ve "Durumsal Bilgi”" şeklindedir. İkinci ana boyut olan Bilişin Düzenlenmesi boyutuna ait 35 madde yer almaktadır. Bilişin Düzenlenmesi boyutu beş alt boyuta ayrılmaktadır. Bu alt boyutlar "Planlama", "Bilgi Yönetimi", "İzleme", "Hata Ayıklama" ve "Değerlendirme" şeklindedir. Üstbilişsel Farkındalık Envanteri maddelerinin alt boyutlara göre dağılımını gösteren Tablo 2 aşağıda verilmiştir.

Tablo 2.Üstbilişsel farkındalık envanteri'nin boyutları ve alt boyutları

\begin{tabular}{lllc}
\hline Boyutlar & Alt Boyutlar & Maddeler & $\begin{array}{c}\text { Madde } \\
\text { Says1 }\end{array}$ \\
\hline Bilişin Bilgisi & Açılkayıcı Bilgi & $5,10,12,16,17,20,32,46$ & 9 \\
& Yöntemsel Bilgi & $3,14,27,33$ & 4 \\
& Durumsal Bilgi & $15,18,26,29,35$ & 5 \\
Bilişin & Planlama & $4,6,8,22,23,42,45$ & 7 \\
Düzenlenmesi & İleme & $1,2,11,21,28,34,49$ & 7 \\
& Değerlendirme & $7,19,24,36,38,50$ & 6 \\
& Hata Ayıklama & $25,40,44,51,52$ & 5 \\
Toplam & Bilgi Yönetme & $9,13,30,31,37,39,41,43,47,48$ & 10 \\
& & & 52 \\
\hline
\end{tabular}

Akın, Abacı ve Çetin (2007) tarafından yapılan envanterin geçerlik çalısması sonucu uyum geçerliliği \% 95, güvenirlik çalışması sonucu envanterin bütünü için test-tekrar test güvenirlik katsayısı 0,95 ve iç tutarll1ık Cronbach Alpha güvenirlik katsayısı 0,95 olarak bulunmuştur. Bu çalışmada envanterin Cronbach Alpha güvenirlik katsayısı ise 0,96 olarak oldukça yüksek ve güvenilir bulunmuştur. 


\subsubsection{Matematik öz yeterlik algısı ölçeği}

Matematik Öz Yeterlik Alg1sı Ölçeği, 14 maddeden oluşmakta olup, bu maddelerin 8 tanesi olumlu, 6 tanesi olumsuz ifade içeren maddeler şeklinde ayrılmaktadır. Beşli Likert tipinde hazırlanan ölçekten alınabilecek en yüksek öz yeterlik algı puanı 70, en düşük 14 puandır. Ölçek üç alt boyuttan oluşmakta olup, bu boyutlar matematik benlik algısı, matematik konularında davranışlarındaki farkındalık ve matematiği yaşam becerilerine dönüştürebilme olarak tanımlanmıştır. Umay (2001) ölçeğin geçerlik analizinde, ölçekteki maddelerin geçerlik katsayılarının ortancasını 0,64 olarak tespit etmiş ve bu değerin ölçeğin tümünün geçerliği konusunda bir ölçüt olarak kabul edilebileceğini ifade etmiştir. Öğretmen adaylarıyla yapılan çalışmada, ölçeğin güvenirlik katsayısı 0,88 olarak bulunmuştur. Bu çalışmada ise güvenirlik katsayısı 0,87 olarak hesaplanmıştır.

\subsubsection{Kişisel bilgi formu}

Kişisel bilgi formu araştırmacı tarafindan hazırlanmış olup, öğrencilerin üstbilişsel farkındalık düzeyi ve matematik öz yeterlik algılarıyla ilişkili olabileceği düşünülen (cinsiyet, sınıf düzeyi, matematik karne notu ve sosyo-ekonomik durum) demografik değişkenlerden oluşmaktadır.

\subsection{Verilerin Analizi}

Verilerin analizinde, istatistik paket programından yararlanılmıştır. Öğrencilerin üstbilişsel farkındalık düzeyleri ile matematik öz yeterlik algılarının cinsiyet değişkenine göre farklılı̆̆ını incelemek amacıyla Bağımsız Gruplar t testi, sınıf ve matematik karne notu değişkenlerine göre farklıllğını incelemek amacıyla tek yönlü varyans analizi (ANOVA) uygulanmıştır.

Bağımsız değişkenler olan üstbilişsel farkındalık düzeyi ve matematik öz yeterlik algısının, bağımlı değişken olan matematik başarısı üzerindeki etkisini belirlemek amacıyla çoklu regresyon analizi yapılmıştır. Bağımsız değişkenler ve bağımlı değişkene ilişkin regresyon analizinin yapılabilmesi için söz konusu bağımsız değisskenlerin her birinin bağımlı değişkenle doğrusal bir ilişki göstermesi gerekmektedir. Bu nedenle regresyon analizinden önce bağımsız değişkenlerle bağımlı değişken arasındaki ilişkiyi belirlemek amacıyla Pearson Momentler Çarpımı Korelasyon analizi yapılmıştır.

Öğrencilerin üstbilişsel farkındalık düzeyinin normal dağılımını belirlemek amacıyla puanların dağılım grafikleri incelenmiş ve verilerin normallikten sapma gösterdiği görülmüştür. Fakat çarpıklık (skewness) değeri -,447 olarak bulunmuştur. Bu değerin -1 ile +1 değerler arasında olması verilerin normal dağıldığını göstermektedir. Bu nedenle verilerin analizinde parametrik testlere yer verilmiştir. Verilerin dağılımına ilişkin histogram grafiği Şekil 1'de verilmiştir.

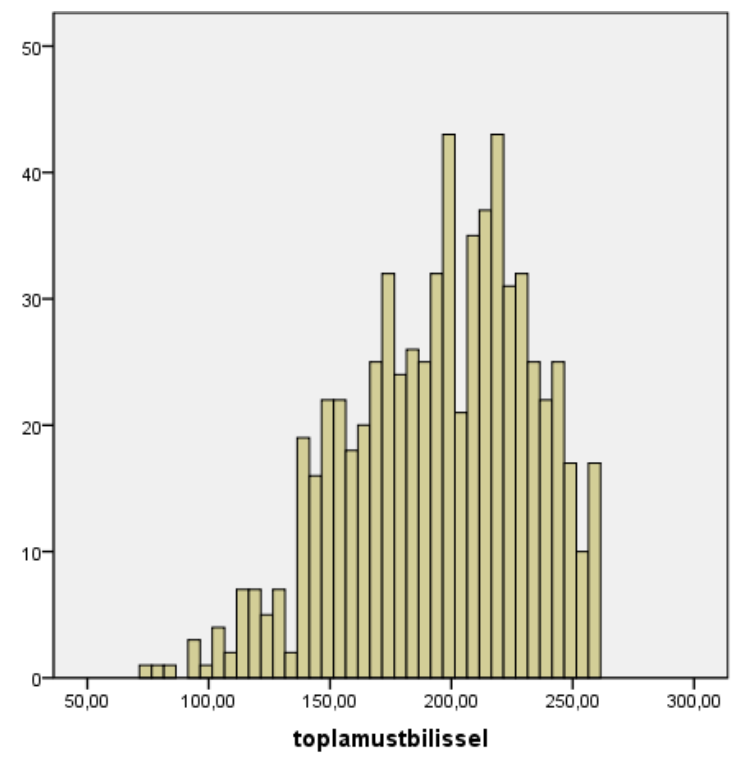

Şekil 1. Üstbilişsel farkındalık düzeyi toplam puanlarının dağılım grafiği

Öğrencilerin matematik öz yeterlik alg1sı puanlarının normal dağılımını belirlemek amacıyla puanların dağglım grafikleri incelenmiş ve verilerin normallikten sapma gösterdiği görülmüştür. Fakat çarpıklık (skewness) değeri -,219 olarak bulunmuştur. Bu değerin -1 ile +1 değerler arasında olması verilerin normal dağıldığını göstermektedir. Bu nedenle verilerin analizinde parametrik testlere yer verilmiştir. Verilerin dağılımına ilişkin histogram grafiği Şekil 2'de verilmiştir. 


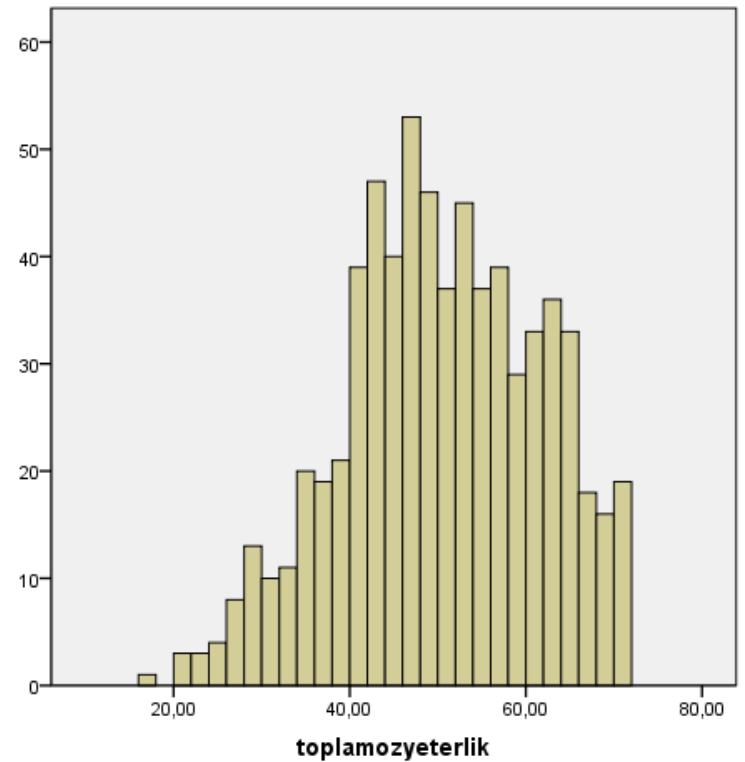

Şekil 2. Matematik öz yeterlik algı düzeyi toplam puanlarının dağılım grafiğ̊

\section{BULGULAR}

Bu bölümde araştırmanın alt problemlerine ait analiz sonuçları ve yorumları yer almaktadır.

\section{1. Üstbilişsel Farkındalık Düzeyinin Farklılı̆g1}

$\mathrm{Bu}$ bölümde araştırmanın birinci alt problemine yönelik bulgular yer almaktadır. Öğrencilerin üstbilişsel farkındalık düzeylerinin cinsiyet, sınıf düzeyi ve matematik karne notu değişkenlerine göre farklıllğı incelenmiştir.

Araştırmaya katılan öğrencilerin üstbilişsel farkındalık düzeylerinin cinsiyete göre farklılaşıp farklılaşmadığını belirlemek amacıyla yapılan Bağımsız gruplar t testi sonuçları Tablo 3' te sunulmuştur.

Tablo 3. Üstbilişsel farkındalık düzeyinin cinsiyet değişkenine göre farklılığ1

\begin{tabular}{llccccc}
\hline & Cinsiyet & $\mathbf{n}$ & $\bar{X}$ & s & t & p \\
\hline \multirow{2}{*}{ Üstbilişsel Farkındalık } & Kiz & 361 & 199.91 & 37.219 & \multirow{2}{*}{3.880} & \multirow{2}{*}{.00} \\
& Erkek & 319 & 188.88 & 36.805 & & \\
\hline
\end{tabular}

Tablo 3 ' te görüldüğü üzere öğrencilerin üstbilişsel farkındalık düzeylerinin cinsiyet değişkenine göre istatistiksel olarak anlamlı farklılık göstermektedir ( $\mathrm{t}=3.880, \mathrm{p}<.05)$. Öğrencilerin üstbilişsel farkındalık düzeylerindeki farklılık kız öğrenciler lehinedir. Bu sonuca göre, kız öğrencilerin üstbilişsel farkındalık düzeyleri erkek öğrencilerden daha yüksektir.

Araştırmaya katılan öğrencilerin üstbilişsel farkındalık düzeylerinin sınıf düzeyine göre farklılaşıp farklılaşmadığını belirlemek amacıyla yapılan tek yönlü varyans analizi sonuçları Tablo 4 ' te sunulmuştur.

Tablo 4. Üstbilişsel farkındalık düzeyinin sınıf düzeyi değişkenine göre farklılığ1

\begin{tabular}{|c|c|c|c|c|c|c|}
\hline & Kaynak & $\begin{array}{l}\text { Kareler } \\
\text { toplamı }\end{array}$ & sd & $\begin{array}{c}\text { Kareler } \\
\text { ortalaması }\end{array}$ & $\mathbf{F}$ & $\mathrm{p}$ \\
\hline \multirow{3}{*}{$\begin{array}{l}\text { Üstbilişsel } \\
\text { Farkındalık }\end{array}$} & Gruplararas1 & 78112.35 & 3 & 26037.45 & & \\
\hline & Grupiçi & 872026.09 & 676 & 1289.97 & 20.18 & 0.00 \\
\hline & Toplam & 950138.44 & 679 & & & \\
\hline
\end{tabular}

Tablo 4 incelendiğinde öğrencilerin üstbilişsel farkındalık düzeylerinin sınıf düzeyine göre istatistiksel olarak anlamlı farklılık gösterdiği görülmektedir $[\mathrm{F}(3-676)=20.18, \mathrm{p}<.05]$. Farklılı̆̆ın hangi gruplardan kaynaklandığını belirlemek üzere varyansların eşit olduğu varsayımına dayanarak yapılan post-hoc Tukey HSD testi sonuçlarına göre :

- Beşinci ve altıncı sınıfta, yedinci sınıfta, sekizinci sınıfta öğrenim gören öğrenciler arasında olup beşinci sınıfta öğrenim gören öğrencilerin lehine,

- Altıncı ve sekizinci sınıfta öğrenim gören öğrenciler arasında olup altıncı sınıfta öğrenim gören öğrencilerin lehine farkllılık gerçekleştiği saptanmıştır. 
Bu bulguya göre üstbilişsel farkındalık düzeyinin özellikle beşinci ve altıncı sınıflanın lehine olması, bu sınıf düzeylerinde öğrenim gören öğrencilerin üst sınıf düzeylerinde öğrenim gören öğrencilere göre daha yüksek üstbilişsel farkındalığa sahip olduklarını ortaya çıarmaktadır.

Araştırmaya katılan öğrencilerin üstbilişsel farkındalık düzeylerinin matematik karne notu değişkenine göre farklılaşıp farklılaşmadığını belirlemek amacıyla yapılan tek yönlü varyans analizi sonuçları Tablo 5'te verilmiştir.

Tablo 5. Üstbilişsel farkındalık düzeyinin matematik karne notu değişkenine göre farklılığ1

\begin{tabular}{lllcccc}
\hline & \multicolumn{1}{c}{ Kaynak } & $\begin{array}{c}\text { Kareler } \\
\text { toplami }\end{array}$ & sd & $\begin{array}{c}\text { Kareler } \\
\text { ortalamasi }\end{array}$ & F & p \\
\hline \multirow{2}{*}{$\begin{array}{l}\text { Üstbilişsel } \\
\text { Farkındalık }\end{array}$} & Gruplararası & 320945.63 & 4 & 80236.40 & & \\
& Grupiçi & 629192.81 & 675 & 932.13 & 86.07 & 0.00 \\
& Toplam & 950138.44 & 679 & & & \\
\hline
\end{tabular}

Tablo 5 incelendiğinde öğrencilerin üstbilişsel farkındalık düzeylerinin matematik karne notu değişkenine göre istatistiksel olarak anlamlı farklılık gösterdiği görülmektedir [ F(4-675) =86.07, p<.05]. Farklılığın hangi gruplardan kaynaklandığını belirlemek üzere varyansların eşit olduğu varsayımına dayanarak yapılan post-hoc Tukey HSD testi sonuçlarına göre:

- Karne notu bir ile karne notu iki, üç, dört ve beş olan öğrenciler arasında olup karne notu iki, üç, dört ve beş olan öğrencilerin lehine,

- Karne notu iki ile karne notu üç, dört ve beş olan öğrenciler arasında olup karne notu üç, dört ve beş olan öğrencilerin lehine,

- Karne notu üç ile karne notu dört ve beş olan öğrenciler arasında olup karne notu dört ve beş olan öğrencilerin lehine,

- Karne notu dört ile karne notu beş olan öğrenciler arasında olup karne notu beş olan öğrencilerin lehine gerçekleştĭgi saptanmıştır.

Bu bulguya göre üstbilişsel farkındalık düzeyinin matematik karne notu yüksek olan öğrencilerin lehine olduğu yani matematik karne notu yüksek olan bireylerin yüksek üstbilişsel farkındalık düzeyine sahip olduğu görülmektedir.

\subsection{Matematik Öz Yeterlik Algısının Farklı1ığı}

$\mathrm{Bu}$ bölümde araştırmanın ikinci alt problemine yönelik bulgular yer almaktadır. Öğrencilerin matematik Öz yeterlik algısının cinsiyet, sınıf düzeyi ve matematik karne notu değişkenlerine göre farkl1lığı incelenmiştir.

Araştırmaya katılan öğrencilerin matematik öz yeterlik algısının cinsiyet değişkenine göre farklılaşıp farklılaşmadığını belirlemek amacıyla yapılan Bağımsız gruplar gruplar t testi sonuçları Tablo 6'da sunulmuştur.

Tablo 6. Matematik öz yeterlik algısının cinsiyet değișkenine göre farklılığı

\begin{tabular}{llccccc}
\hline & Cinsiyet & $\mathbf{n}$ & $\bar{X}$ & s & t & p \\
\hline \multirow{2}{*}{ Matematik Öz Yeterlik Alg1s1 } & Kiz & 361 & 50.05 & 11.581 & \multirow{2}{*}{0.542} & .58 \\
& Erkek & 319 & 49.59 & 10.553 & & \\
\cline { 2 - 6 }
\end{tabular}

Tablo 6’ya göre öğrencilerin matematik öz yeterlik alg1ları cinsiyete göre istatistiksel olarak anlamlı bir farklılık göstermemektedir ( $\mathrm{t}=0.542, \mathrm{p}>.05)$. Araştırmaya katılan öğrencilerin matematik öz yeterlik algısının sınıf değişkenine göre farklılaşıp farklılaşmadığını belirlemek amacıyla yapılan tek yönlü varyans analizi sonuçları Tablo 7'de sunulmuştur. 
Tablo 7. Matematik öz yeterlik algısının sınıf düzeyi değişkenine göre farklılı̆̆1

\begin{tabular}{|c|c|c|c|c|c|c|}
\hline & Kaynak & $\begin{array}{l}\text { Kareler } \\
\text { toplamı }\end{array}$ & sd & $\begin{array}{c}\text { Kareler } \\
\text { ortalaması }\end{array}$ & $\mathbf{F}$ & $\mathrm{p}$ \\
\hline Matematik & Gruplararas1 & 6975.03 & 3 & 2325.01 & & \\
\hline Öz Yeterlik & Grupiçi & 76767.81 & 676 & 113.56 & 20.47 & 0.00 \\
\hline Alg1sı & Toplam & 83742.84 & 679 & & & \\
\hline
\end{tabular}

Tablo 7 incelendiğinde ögrencilerin matematik öz yeterlik algılarının sınıf düzeyi değişkenine göre istatistiksel olarak anlamlı farklılık gösterdiği görülmektedir $\quad(\mathrm{F}(3-676)=20.47, \mathrm{p}<.05)$. Farklılı̆̆ın hangi gruplardan kaynaklandığını belirlemek üzere varyansların eşit olduğu varsayımına dayanarak yapılan post-hoc Tukey HSD testi sonuçlarına göre :

- Beşinci ve altıncı sınıfta, yedinci sınıfta, sekizinci sınıfta öğrenim gören öğrenciler arasında olup beşinci sınıfta öğrenim gören öğrencilerin lehine,

- Altıncı ve sekizinci sınıfta öğrenim gören öğrenciler arasında olup altıncı sınıfta öğrenim gören öğrencilerin lehine

gerçekleştiği saptanmıştır.

Bu bulguya göre matematik öz yeterlik algısının özellikle beşinci ve altıncı sınıfların lehine olması, bu sınıf düzeylerinde öğrenim gören öğrencilerin üst sınıf düzeylerinde öğrenim gören öğrencilere göre daha yüksek matematik öz yeterlik algsına sahip olduklarını ortaya çıkarmaktadır.

Araştırmaya katılan öğrencilerin matematik öz yeterlik algılarının matematik karne notu değişkenine göre farklılaşıp farklılaşmadığını belirlemek amacıyla yapılan tek yönlü varyans analizi sonuçları Tablo 8'de sunulmuştur.

Tablo 8. Matematik öz yeterlik algısının matematik karne notu değişkenine göre farklılı̆̆1

\begin{tabular}{cllcccc}
\hline & Kaynak & $\begin{array}{c}\text { Kareler } \\
\text { toplami }\end{array}$ & sd & $\begin{array}{c}\text { Kareler } \\
\text { ortalamas1 }\end{array}$ & F & p \\
\hline Matematik & Gruplararas1 & 38308.21 & 4 & 9577.05 & & \\
Öz Yeterlik & Grupiçi & 45434.63 & 675 & 67.31 & 142.28 & 0.00 \\
Algısı & Toplam & 83742.84 & 679 & & & \\
\hline
\end{tabular}

Tablo 8 incelendiğinde öğrencilerin matematik öz yeterlik algılarının matematik karne notu değişkenine göre istatistiksel olarak anlamlı farklılık gösterdiği görülmektedir [ $\mathrm{F}(4-675)=142.28, \mathrm{p}<.05]$. Farklılığın hangi gruplardan kaynaklandığını belirlemek üzere varyansların eşit olduğu varsayımına dayanarak yapılan post-hoc Tukey HSD testi sonuçlarına göre:

- Karne notu bir ile karne notu üç, dört ve beş olan öğrenciler arasında olup karne notu üç, dört ve beş olan öğrencilerin lehine,

- Karne notu iki ile karne notu üç, dört ve beş olan öğrenciler arasında olup karne notu üç, dört ve beş olan öğrencilerin lehine,

- Karne notu üç ile karne notu dört ve beş olan öğrenciler arasında olup karne notu dört ve beş olan öğrencilerin lehine,

- Karne notu dört ile karne notu beş olan öğrenciler arasında olup karne notu beş olan öğrencilerin lehine gerçekleştiği saptanmıştır.

$\mathrm{Bu}$ bulgu matematik karne notu yüksek olan öğrencilerin aynı zamanda yüksek matematik öz yeterlik algısına sahip olduklarını göstermektedir.

\section{3.Üstbilişsel Farkındalık Düzeyi ile Matematik Öz Yeterlik Algısının Matematik Başarısına}

\section{Etkisi}

Bu bölümde üçüncü, dördüncü ve beşinci alt problemlerin bulguları yer almaktadır. Bağımsız değişkenler olan üstbilişsel farkındalık düzeyi ve matematik öz yeterlik algısının bağımlı değişken olan matematik başarısı üzerindeki etkisini belirlemek amacıyla regresyon analizi yapılmıştır. Bağımsız değişkenler ve bağımlı değişkene ilişkin regresyon analizinin yapılabilmesi için söz konusu bağımsız değişkenlerin her birinin bağımlı değişkenle doğrusal bir ilişki göstermesi gerekmektedir (Karasar, 2000; Akt: Canca, 2005; 57). Bu nedenle regresyon 
analizinden önce bağımsız değişkenlerle bağımlı değişken arasındaki ilişkiyi belirlemek amacıyla Pearson Momentler Çarpımı Korelasyon analizi yapılmıştır. Üçüncü ve dördüncü alt problemlere ait korelasyon analiz sonuçları Tablo 9'da sunulmuştur.

Tablo 9. Öğrencilerin üstbilişsel farkındalık düzeyleri ve matematik öz yeterlik algıları ile matematik başarıları arasındaki korelasyon analizi sonuçları

\begin{tabular}{lcc}
\hline & \multicolumn{3}{c}{ Matematik Başarısı } \\
\hline & $\mathbf{r}$ & $\mathbf{p}$ \\
\hline Ustbilişsel Farkındalık & 0.580 & $.00^{*}$ \\
Matematik Öz Yeterlik Alg1sı & 0.672 & $.00^{*}$ \\
\hline $\mathrm{n}=680, \mathrm{p}<.05^{*}$ & &
\end{tabular}

$\mathrm{n}=680, \mathrm{p}<.05^{*}$

Tablo 9 incelendiğinde öğrencilerin matematik başarısı ile üstbilişsel farkındalık düzeyi arasında pozitif yönde orta düzeyde $(\mathrm{r}=0.580, \mathrm{p}<.05)$; matematik başarısı ile matematik öz yeterlik algısı arasında pozitif yönde orta düzeyde $(\mathrm{r}=0.672, \mathrm{p}<.05)$ anlamlı ilişki olduğu görülmektedir.

Araştırmanın beşinci alt problemine ait matematik başarısı üzerindeki etkinin belirlenmesine ilişkin çoklu regresyon analizi sonuçları Tablo 10'da sunulmuştur.

Tablo 10. Üstbilișsel farkındalık düzeyi ve matematik öz yeterlik algısının matematik bașarısına etkisi

\begin{tabular}{|c|c|c|c|c|c|}
\hline & \multicolumn{2}{|c|}{ Standart puanlar } & \multirow{2}{*}{$\begin{array}{l}\text { Standartlaştırılmış } \\
\text { puanlar } \\
\text { Beta }\end{array}$} & \multirow{2}{*}{$\mathbf{t}$} & \multirow{2}{*}{$\mathrm{p}$} \\
\hline & B & SH & & & \\
\hline Sabit & -0.933 & 0.190 & & -4.904 & $.000^{*}$ \\
\hline $\begin{array}{l}\text { Üstbilişsel } \\
\text { Farkındalık }\end{array}$ & 0.009 & 0.001 & 0.263 & 7.526 & $.000^{*}$ \\
\hline $\begin{array}{l}\text { Matematik Öz } \\
\text { Yeterlik Alg1s1 }\end{array}$ & 0.057 & 0.004 & 0.508 & 14.511 & $.000 *$ \\
\hline
\end{tabular}

Tablo 10 incelendiğinde, öğrencilerin matematik başarıları üzerindeki etkinin belirlenmesine ilişkin çoklu regresyon analizi sonucunda, bağımsız değişkenlere ilişkin $\mathrm{t}$ değerlerinin, üstbilişsel farkındalık düzeyi için $\mathrm{p}=$ .00 anlamlılık düzeyinde 7.526; matematik öz yeterlik algrsı için $\mathrm{p}=.00$ anlamlılık düzeyinde 14.511 bulunduğu görülmektedir. Söz konusu değişkenlerin birlikte başarıya etkisini belirlemeye ilişkin $\mathrm{F}$ değeri ise $\mathrm{p}=.00$ anlamllık düzeyinde 330.436 olarak hesaplanmıştır. Diğer değişkenlerin etkisi sıfırlandığında, üstbilişsel farkındalık düzeyi ve matematik öz yeterlik alg1sı birlikte bağımlı değişken olan matematik başarısı üzerindeki değişkenliğin yaklaşık \%49’unu açıklamaktadır. Bu bulguya göre üstbilişsel farkındalık ve matematik öz yeterlik algısının matematik başarısı üzerinde anlamlı etkiye sahip olduğu ortaya çıkmaktadır.

\section{TARTIŞMA ve SONUÇ}

Araştırmanın bu bölümünde, araştırmadan elde edilen bulguların sonuçları literatüre dayalı olarak tartışılmış ve elde edilen sonuçlardan hareketle geliştirilen önerilere yer verilmiştir.

Öğrencilerin üstbilişsel farkındalık düzeyinin cinsiyet değişkenine göre istatistiksel olarak anlamlı farklılık gösterdiği tespit edilmiştir. Öğrencilerin üstbilişsel farkındalık düzeylerindeki farklılık kız öğrenciler lehinedir. Bu sonuca göre, kız öğrencilerin üstbilişsel farkındalık düzeyleri erkek öğrencilerden daha yüksektir. Üstbilişsel farkındalık düzeyleri ve üstbiliş stratejilerin cinsiyetler üzerinde etkisi ile ilgili yapılan araştırmalarda da benzer sonuçlar elde edilmiştir (Akçam, 2012; Aktaş, 2013; Alcı \& Altun, 2007; Ateş, 2013; Bağçeci, Döş \& Sarıca, 2011; Canca, 2005; Demir \& Özmen, 2011; Dilci \& Kaya, 2012; Saban \& Saban, 2008; Topçu \& Tüzün, 2009; Tunca \& Şahin, 2014). Üstbilişsel farkındalığın cinsiyet değişkenine göre anlamlı düzeyde farklılık göstermediği çalışmalar da bulunmaktadır (Aydın \& Coşkun, 2011; Balcı, 2007; Çikrıkci \& Odacı, 2013; Kışkır, 2011; Memnun \& Akkaya, 2009; Özsoy \& Günindi, 2011; Sapanc1, 2012; Tüysüz, Karakuyu \& Bilgin, 2008). Liliana ve Lavinia' nın (2011) yaptıkları çalışma ise hem kızların hem de erkeklerin öğrenimde üstbilişsel farkındalık becerilerini kullandıklarını ortaya koymaktadır. Topçu ve Tüzün’e (2009) göre, ilköğretim öğrencilerinin üstbilişsel farkındalıklanının gelişiminde cinsiyet önemli bir değişkendir. Bu araştırmanın sonucuna göre kız öğrencilerin daha yüksek üstbilişsel farkındalı̆ga sahip olmaları, kız öğrencilerin biyolojik yapısından kaynaklanan ayrıntılı düşünme becerisine sahip olmalarının ve dikkatlerini yoğunlaştırmada iyi olmalarının etkili olabileceği düşünülmektedir.

Öğrencilerin üstbilişsel farkındalık düzeylerinin, sınıf düzeyi değişkenine göre incelendiğinde istatistiksel olarak anlamlı bir farklılık gösterdiği tespit edilmiştir. Gruplar arasında farklılı̆ga bakıldığında, alt sınıf düzeylerinin lehine farklılık olduğu görülmüştür. Gruplar arası farklıı̆ı̆n yedinci ve sekizinci sınıf 
öğrencilerinin lehine olması beklenirken tam tersi bir durum söz konusudur. Bunun sebebi ülkemizde yapılan eğitim sistemi değişikliklerine hem öğrencilerin hem de onların üstbilişsel farkındalıklarının gelişmesine eğitimle yardımcı olacak öğretmenlerimizin adapte olamaması olabilir. Ülkemizde 2005 y1lı itibarıla yapılandırmacı yaklaşım benimsenmiş fakat uygulamaya geçilmesi zaman almıştır. Yani birçok öğretmenin, yapılandırmacı anlayışı derslerine entegre edemeyişi ögrencilerin sınıf düzeylerinde böyle bir farklılığa sebep olmuş olabilir. Sınıf ortamlarının iyileştirilmesi, teknolojik anlamda okulların desteklenmesiyle ortaokula yeni başlamış öğrencilerde yapılandırmacı yaklaşıma uygun ders işleyişi gerçekleşmektedir. Üst sınıf düzeylerinde öğrencilerin sadece sınava hazırlanıyor olmaları ve eskiden gelen geleneksel, ezberci anlayış, üstbilişsel farkındalı̆ğ geliştirici etkinliklere daha az yer verilmesine sebep olabilir. Buradan hareketle sınıf düzeyleri arasında bu farklılığın çıkması ve özellikle alt sınıfların lehine gerçekleşmesi olağandır. Nitekim Yurdakul (2004) yaptığı çalışmada yapılandırmacı öğrenme yaklaşımı uygulamalarına katılan öğrencilerin üstbilişsel farkındalıklarının geliştiğini, geleneksel yaklaşım uygulamalarının üstbilişsel farkındalığı geliştirmede önemli bir etkisinin olmadığ1 sonucunu ortaya çıkarmıştır. Ek olarak yapılan birçok deneysel çalışmada deney grubuna yapılandırmacı öğrenme yaklaşımı esaslı öğretim yöntemleri veya üstbiliş stratejileri uygulanırken, kontrol grubuna geleneksel öğretim yöntemleri uygulanmıştır. $\mathrm{Bu}$ çalısmalardan, üstbilişsel farkındalığın geliştirilebileceğine dair sonuçlar elde edilmiştir (Baltac1, 2009; Demircioğlu, 2008; Demirsöz, 2010; Ektem, 2007; Gelen, 2003). Bu sonuçla benzer olarak Demir ve Özmen'in (2011) araştırmasının sonuçlarına göre uyguladığ1 üst biliş ölçeğinin, kontrol edilemezlik ve tehlike boyutunda beşinci sınıf ortalamasının, dördüncü, üçüncü, ikinci ve birinci sınıf öğrencilerine göre daha düşük olduğu görülmüştür. Kışkır'ın (2011) çalışmasında ise sınıf düzeyi açısından öğretmen adaylarının üstbilişsel farkındalık envanteri toplam ve alt boyutlarına ilişkin puanları değerlendirildiğinde, gruplar arasında anlamlı farklılaşma olmadığı belirlenmiştir. Ancak ortalamalar açısından bakıldığında üçüncü sınıf öğrencilerinin üstbilişsel farkındalık düzeylerinin dördüncü sınıflara göre yüksek olduğu belirlenmiştir. Benzer olarak Akçam (2012) ise ortaokul öğrencileriyle yaptığ çalışmada, öğrencilerin sınıf seviyelerinin üstbilişsel farkındalık envanterine ilişkin görüşlerinin altıncı ve yedinci sınıflar lehine anlamlı olduğunu belirlemiştir. Baysal, Ayvaz, Çekirdekçi ve Malbeleği (2013) yaptıkları araştırmalarında, üstbilişsel farkındalık düzeyinin sınıf değişkenine göre farklılaştığını ve son sınıflar lehine olduğunu belirtmişlerdir. Tüysüz, Karakuyu ve Bilgin (2008) yaptıkları çalışmada sınıf düzeyleri arttıkça öğrencilerin üstbiliş düzeylerinde artma olduğunu tespit etmişlerdir. Özsoy ve Günindi (2011) çalışmalarının sonucunda, okulöncesi öğretmenliği lisans programında öğrenim görmekte olan öğretmen adaylarının üstbilişsel farkındalık puanlarının sınıf düzeyine göre dördüncü sınıflar lehine farklılaştığını ifade etmişlerdir. Literatür incelendiğinde üstbilişsel farkındalık düzeyinin sınıf düzeyi değişkenine göre anlamlı farklılığı olmadığına dair araştırmalar da mevcuttur (Aydın \& Coşkun, 2011; Saban \& Saban, 2008; Sapanc1, 2012). Temur, Kargın ve Bayar (2010) araştırmaları sonucunda, sınıf seviyesi ile üstbilişsel farkındalık arasında olumlu bir ilişki olduğu ancak bu ilişkinin istatistiksel açıdan anlamlı olmadığı sonucuna varmışlardır. Üstbilişsel farkındalık düzeyinin sınıf düzeyine göre farklılık olmadığını belirten çalışmalar, sınıf düzeyi arttıkça öğrencilerin gelişiminin de ilerlediğini ve dolayısıyla üstbiliş farkındalıklarının geliştiği varsayımını ortaya koymaktadır.

Öğrencilerin üstbilişsel farkındalık düzeylerinde matematik karne notu değişkenine göre istatistiksel olarak anlamlı farklılık görülmektedir. Farklılığın matematik karne notu yüksek olan öğrencilerin lehine olduğu görülmektedir. Matematik karne notu yüksek yani matematik başarısı yüksek bireylerin üstbilişsel farkındalıklarının daha yüksek olduğu sonucuna ulaşılabilir. Bu sonuç olağan kabl edilebilir. Çünkü üstbilişsel farkındalık, akademik başarıya yardımcı olan önemli bir unsurdur. Öğrenme çalışmalarını planlayan, izleyen ve değerlendiren ve bilişsel süreçlerine ilişkin farkındalık sahibi olan öğrencilerin akademik başarıya ulaşmaları doğaldır. Literatürde bu sonuç ile benzerlik gösteren birçok çalışma mevcuttur (Aktürk \& Şahin, 2011; Çalışkan \& Sünbül, 2010; Çikrıkci \& Odac1, 2013; Durdukoca, 2013; Sapanc1, 2012; Tok, Özgan \& Döş, 2010; Tunca \& Şahin, 2014; Tuncer, 2011).

Öğrencilerin matematik öz yeterlik algilarının cinsiyete göre istatistiksel olarak anlamlı farklılık göstermediği tespit edilmiştir. $\mathrm{Bu}$ sonuç, literatürde yer alan bazı araştırma sonuçlarıyla paralellik göstermektedir (Akay \& Boz, 2011; Gülten \& Soytürk, 2013; Goodwin, Ostrom \& Scott, 2009; Gündoğdu, 
2013; Işıksal \& Aşkar, 2003; Pişkin \& Durmuş, 2010). Matematik öz yeterlik algısının cinsiyet değişkenine göre anlamlı düzeyde farklılık gösterdiği çalışmalar da bulunmaktadır (Pajares, 2005; Reçber, 2011; Tella, 2011; Terzi \& Mirasyedioğlu, 2009; Yağmur, 2012; Yenilmez \& Kakmac1, 2008). Pajares ve Miller (1994) yaptıkları çalışmada erkek öğrencilerin kız öğrencilere kıyasla matematik öz yeterlik algılarının daha yüksek olduğunu tespit ederken, Öztürk ve Şahin (2015) beşinci sınıf öğrencileri ile yaptıkları çalışmanın sonuçları matematik öz yeterlik algısının kız öğrenciler lehine farklılaştı̆̆ı yönündedir. Çakıroğlu ve Işıksal (2009) ise çalışmaları sonucunda, öğretmen adaylarının matematiğe yönelik öz yeterlik algılarının cinsiyete göre anlamlı farklılık gösterdiği, erkek öğrencilerin kız öğrencilere oranla anlamlı düzeyde daha yüksek ortalamaya sahip olduklarını belirtmişlerdir. Literatür incelendiğinde, matematik öz yeterlik algısının cinsiyet değişkenine göre farklılı̆̆ını ele alan çalışmaların farklı sonuçlar ortaya koydukları görülmektedir. Bu çalışmanın sonucunun farklı olmasının farklı örneklem ile çalışılmasından kaynaklanıyor olabileceği düşünülmektedir.

Öğrencilerin matematik öz yeterlik algıları sınıf düzeyi değişkenine göre incelendiğinde istatistiksel olarak anlamlı farklılık gösterdiği tespit edilmiştir. Gruplar arasında farklıllğa bakıldığında alt sınıf düzeylerinin lehine farklılık olduğu görülmüştür. Sınıf düzeyinin artması ile birlikte 8. sınıfta öğrencilerin karşısına ortaöğretime geçiş sınavı çıkmaktadır. Bu sınava hazırlanma sürecinde, öğrenciler karşılaştıkları güçlükler ile birlikte öğrencilerin öz yeterlik algılarında bir azalma oluştuğu düşünülmektedir. Bu sonuçla benzer olarak, yapılan bazı araştırmalarda öğrencilerin matematik öz yeterlik algılarının sınıf düzeyine göre farklılaştığı ve sınıf düzeyi düşük olan öğrencilerin, yüksek olan öğrencilere göre matematik öz yeterlik algılarının daha yüksek olduğu tespit edilmiştir (Yağmur, 2012; Yenilmez \& Kakmacı, 2008). Matematik öz yeterlik algısının sınıf düzeyine göre farklılaştı̆̆ı fakat bu farklılığın üst sınıf seviyesindeki öğrencilerin lehine olduğunu ifade eden araştırmalar da mevcuttur (Çakıroğlu \& Işıksal, 2009; Umay, 2001). Matematik öz yeterlik algısının sınıf düzeyi değişkenine göre anlamlı düzeyde farklılık göstermediği çalışmalar da bulunmaktadır. Gündoğdu (2013) yedinci ve sekizinci sınıfta öğrenim gören öğrencilerin sahip olduğu matematiksel güç ile matematik öz yeterlik algisı arasındaki ilişkiyi ortaya koymaya çalıştığı araştırmasında, öğrencilerin matematik öz yeterlik algılarının sınıf düzeyine göre farklılaşmadığını belirtmiştir. Matematik öz yeterlik algısının sınıf düzeyine göre farklılık göstermediğini kabul eden çalışmalar, öğrencilerin kendi yeterlikleri hakkında kararlarının sınıf düzeyine bağlı olmadığını ortaya çıkarmışlardır. Bu durum öğrencilerin bulundukları psikolojik durum, performans, bireysel farklılıklar gibi değisskenlerin matematik öz yeterlik algısı üzerinde etkili unsurlar olabileceğini ve sınıf düzeyi, yaş gibi değişkenlerin matematik öz yeterlik alg1sı üzerinde etkili olmadığı düşüncesi üzerine yoğunlaştırmaktadır.

Öğrencilerin matematik öz yeterlik algılarının matematik karne notu değişkenine göre istatistiksel olarak anlamlı farklılık gösterdiği görülmektedir. Gruplar arasındaki farklılığa bakıldığında, karne notu yüksek olan öğrencilerin lehine farklılık olduğu ortaya çımaktadır. Bu çalışmada matematik karne notu matematik başarısına işaret etmektedir. Matematik başarı düzeyine göre matematik öz yeterlik algısının farklılaşıp/farklılaşmadığına ilişkin yapılan çalışmalar incelendiğinde, öğrencilerin matematiğe ilişkin akademik başarısına göre matematik öz yeterlik algısının olumlu yönde etkilendiği belirlenmiştir (Çelik, 2012; Öztürk \& Şahin, 2015; Pajares \& Miller, 1994). Bu sonuçla çelişkili olan Gündoğdu (2013) araştırmasında, öğrencilerin matematik öz yeterlik algılarının matematik karne notuna göre farklılaşmadığını ortaya koymuştur. Öğrencilerin matematik öz yeterlik algısının matematik karne notuna göre farklılaştığına ilişkin elde edilen sonuç ve ilgili araştırma sonuçları birlikte değerlendirildiğinde, matematik başarıları yüksek olan öğrencilerin matematik öz yeterlik algılarının da arttığı söylenebilir.

Öğrencilerin matematik başarısı ile üstbilişsel farkındalık düzeyi arasında pozitif yönde, orta düzeyde, anlamlı bir ilişki olduğu tespit edilmiştir. Bu sonucu destekleyen benzer araştırmalar da bulunmaktadır. Üstbilişsel farkındalık ve üstbilişs stratejilerin matematik başarısı ile ilişkisine yönelik çalışmalara bakıldığında; matematik başarısı ile üstbiliş stratejilerinin anlamlı bir ilişkiye sahip olduğu (Canca, 2005; Ekenel, 2005; Özsoy, 2007; Ektem, 2007; Çelik, 2012), üstbilişsel farkındalık düzeyi puanları ile matematik başarı puanları arasında ilişkinin var olduğu (Balc1, 2007) araştırma sonuçlarıyla benzerlik gösterirken Yıldız (2010)'n üstbilişsel stratejilerin matematik başarısı üzerinde anlamlı etkisi olmadığı bulgusuyla farklılık göstermektedir. Araştırma sonuçlarına ve ilgili çalışmalara bakıldığında, öğrencilerin üstbilişsel farkındalık düzeyleri arttıkça 
matematik başarılarının arttı̆̆ı yani aralarında bir ilişki olduğu söz konusudur. Kendi bilişsel süreçlerini kontrol eden, öğrenme süresince biliş bilgisine sahip olan ve bilişsel becerilerini nasıl kullandığının farkında olan öğrencilerin başarıyı elde edeceği düşünülmektedir.

Öğrencilerin matematik başarıları ile matematik öz yeterlik algıları arasında pozitif yönde, orta düzeyde, anlamlı bir ilişki olduğu tespit edilmiştir. Bu sonucu destekleyen birçok çalışma bulunmaktadır (Pajares ve Miller, 1994; Üredi ve Üredi, 2005; Yenilmez ve Kakmac1, 2008; Çağlayan, 2010; Duran, 2011; Tella, 2011; Kitsantas vd., 2011; Reçber, 2011; Çelik, 2012; Çağırgan-Gülten ve Soytürk, 2013; Abalı-Öztürk ve Şahin, 2015). Çalışmadan elde edilen başarı düzeyi arttıkça öz yeterlik algısının da aynı yönde artması sonucu, öğrencilerin matematik başarısı ile matematik öz yeterlik algısının ilişkili olduğunu ortaya koymaktadır. Bu durum, kendisinin matematikte yeterli olduğu algısına sahip öğrencilerin matematik başarılarının da olumlu yönde etkilendiğini ortaya koymaktadır. Yüksek matematik öz yeterlik alg1sına sahip öğrencilerin, düşük matematik öz yeterlik algısına sahip öğrencilere göre daha fazla gayret gösterdikleri, stres düzeylerini kontrol altına alabildikleri, bulundukları duruma uygun kararları verebilmede daha etkili yaklaşımları ortaya koydukları görülmektedir (Ural, 2007; Duran, 2011). Bu nedenle öğrencilerin matematik dersine olan öğrenme istekleri ve başarma duygusu için gayret göstermeleri ve böylece başarıyı yakalamaları beklenen bir durumdur.

Öğrencilerin üstbilişsel farkındalık düzeyi ve matematik öz yeterlik algısının matematik başarısı üzerinde anlamlı etkisinin olduğu ve söz konusu değişkenlerin matematik başarısı üzerindeki değişkenliğin \%49’unu açıkladığı tespit edilmiştir. Elde edilen sonuçlara göre matematik başarısının üzerinde etkili olan iki değişkenin birlikte matematik başarısını ne oranda açıkladığı ortaya koyulmuştur. Bu oranın \%50 ye yakın olması, bu iki değişkenin matematik başarısı için ne kadar önemli olduğunu göstermektedir. Bununla birlikte matematik başarısını etkileyen, araştırılması gereken kavramlar olduğu da ortaya çıkmaktadır. Ortaokul öğrencileriyle yapılan bu çalışma hem araştırmacılara hem de ortaokullarda çalışan öğretmenlere büyük katkı sağlayacaktır. Öğrencilerinin başarılarını etkileyen unsurların ne olduğunu bilen bir öğretmen, öğrencilerine öğrenme sürecinde rehberlik ederken, başarıya giden engelleri de ortadan kaldırabileceklerine inanmalarını sağlayacaktır.

Araştırmadan ile ulaşılan sonuçlar doğrultusunda şu önerilerde bulunulmaktadır:

- Eğitim- öğretim ortamlarında öğrencilerin matematik öz yeterlik algılarının geliştirilmesine yönelik yaratıcı drama, rol yapma gibi tekniklerinin kullanıldığı etkinlikler düzenlenebilir. Bu tarz etkinlikler öğrencilerin kendilerinde var olan potansiyellerini ortaya çıkarmada yardımcı olabilir ve kendilerine olan algılarının gelişmesinde etkili olabilir.

- Öğretmenlerin üstbiliş, üstbilişsel beceri, üstbilişsel farkındalıkların tanımı, işlevleri ve öğretimdeki yeri konusunda bilgilendirilmesi, derslerinde öğrencilerin bu becerilerinin gelişimine yönelik uygulamalarda bulunması sağlanmalıdır.

- Öğretmenlere öğrencilerin üstbilişsel farkındalıklarını gelişmesinde yardımcı olacak bilgi ve iletişim teknolojileri esaslı etkinliklerin düzenlenmesinin gerekliliği hakkında hizmetiçi eğitim verilebilir.

- Eğitim fakültelerinde öğrenim gören öğretmen adayları üstbilişsel farkındalık düzeyinin ve matematik öz yeterlik algısının başarıda önemli unsurlar olduğu hakkında bilgilendirilebilir.

- Araştırmacılar tarafından üstbilişsel farkındalık düzeyinin sınıf düzeyi değişkenine göre farklılaşmasında etkili olduğu düşünülen sınıf içi öğretim yöntem ve tekniklerinin incelemesi yap1labilir.

- Üstbilişsel farkındalık ve matematik öz yeterlik algısı üzerine farklı yaş gruplarına göre ülkemizde yeteri kadar araştırma yapılmadı̆̆ından, bu konuda çalışmalar yapılabilir.

- Üstbilişsel farkındalık ve matematik öz yeterlik algısı yapılarının incelendiği ve bu araştırmadaki yöntemin dişında farklı bir metodun kullanıldığı çalışmaların yapılması, farklı bulguların elde edilmesine yardımcı olabilir. Deneysel yöntemle yapılacak çalışmalar yeni bakış açıları ortaya koyabilir. 


\section{KAYNAKÇA}

Akay, H. \& Boz, N. (2011). Sınıf öğretmeni adaylarının matematiğe yönelik tutumları, matematiğge karşı özyeterlik algıları ve öğretmen öz-yeterlik inançları arasındaki ilişkilerin incelenmesi. Türk Eğitim Bilimleri Dergisi, 9(2), 281-312.

Akçam, S. (2012). Illkögretim 6, 7 ve 8. sinf ögrencilerinin bilis̈̈stü farkendalık düzeylerinin incelenmesi (Doktora tezi). Alınan yer http://acikerisim.deu.edu.tr/xmlui/handle/12345/6972.

Akın, A., Abacı, R. \& Çetin, B. (2007). Bilişötesi Farkındalık Envanteri'nin Türkçe formunun geçerlik ve güvenirlik çalışması. Kuram ve Uygulamada Eğitim Bilimleri, 7(2), 655-680.

Aktaș, A. (2013). Türkçe ögretimi dersi bașan düzeyi ile tutum ve üstbilișsel becerilerin etkileșimi (Yüksek lisans tezi). Alınan yer http://dspace.trakya.edu.tr:8080/jspui/handle/1/1550.

Aktürk, A. O. \& Şahin, İ. (2011). Üstbiliş ve bilgisayar öğretimi. Selçuk Üniversitesi Abmet Keleşoğlu Eğitim Fakültesi Dergisi, 31, 383-407.

Akyol, G. (2009). The contribution of cognitive and metacognitive strategy use to seventh grade students' science achievement (Yayınlanmamış yüksek lisans tezi). Middle East Technical University, Ankara.

Alc1, B. (2007). Yıldı Teknik Üniversitesi ögrencilerinin, matematik başarlar ile algıladıklar problem çözme becerileri, öz yeterlike algular bilisüstü özdüzenleme stratejileri ve ÖSS sayısal puanlar arasindaki açılayıcı ve yordayıc iliskiler örüntüsü (Yayınlanmamış doktora tezi). Yıldız Teknik Üniversitesi, İstanbul.

Alc1, B. \& Altun, S. (2007). Lise öğrencilerinin matematik dersine yönelik özdüzenleme ve bilişüstü becerileri, cinsiyete, sınıfa ve alanlara göre farklılaşmakta mıdır?. C..Ü. Sosyal Bilimler Enstitïsü Dergisi, 16(1), 33-44.

Ataalkın, A. N. (2012). Üst bilisssel ögrretim stratejilerine dayal ögretimin ögrencilerin üst bilissel farkındalı ve becerisine, akademik başar ile tutumuna etkisi (Yayınlanmamıs yüksek lisans tezi). Akdeniz Üniversitesi, Antalya.

Ateş, A. (2013). Üniversite öğrencilerinin okuma stratejileri üstbilişsel farkındalık düzeyleri. Uluslararası Türkşe Edebiyat Kültür Eg̈itim Dergisi, 2(4), 258-273.

Aydın, F. \& Coşkun, M. (2011). Geography teacher candidates' metacognitive awareness levels: A case study from Turkey. Archives of Applied Science Research, 3(2), 551-557.

Bağçeci, B., Döş, B. \& Sarıca, R. (2011). İlköğretim öğrencilerinin üstbilişsel farkındalık düzeyleri ile akademik başarısı arasındaki ilişkinin incelenmesi [An analysis of metacognitive awareness levels and academic achievement of primary school students]. Mustafa Kemal Üniversitesi Sosyal Bilimler Enstitüsü Dergisi, 8(16), 551-566.

Balc1, G. (2007). İlköğretim 5. sinf öğrencilerinin sözel matematike problemlerini çözme düzeylerine göre bilissel farkındahk becerilerinin incelenmesi (Yayınlanmamış yüksek lisans tezi). Çukurova Üniversitesi, Adana.

Baltacı, M. (2009). Web tabanl excel ögrretiminin ögrencilerin akademik başarısı ve bilişötesi farkendalık düzeyine etkisi (Yayınlanmamıs yüksek lisans tezi). Firat Üniversitesi, Elazığ.

Baysal, Z. N., Ayvaz, A., Çekirdekçi, S. \& Malbeleği, F. (2013). Sınıf öğretmeni adaylarının üstbilişsel farkındalıklarının farklı değisskenler açısından incelenmesi. M.Ü. Atatürk Eğitim Fakültesi Eğitim Bilimleri Dergisi, 37, 68-81.

Büyüköztürk, Ş., Çakmak, E. K., Akgün, Ö. E., Karadeniz, Ş. \& Demirel, F. (2011). Bilimsel araștirma yöntemleri. Ankara: Pegem.

Canca, D. (2005). Cinsiyete göre üniversite ögrencilerinin kullandiklar bilisssel ve bilișüstü öz düzenleme stratejileri ile akademik başarlar arasindaki ilişkinin incelenmesi. (Yayınlanmamıs yüksek lisans tezi). Yıldız Teknik Üniversitesi, İstanbul.

Candan, A. S. (2005). Üstbilişsel kuram ve tarih öğretimi. Kastamonu Eğitim Dergisi, 13(2), 327-332.

Çağlayan, S. (2010). Lise 1. simf ögrencilerinin geometri dersine yönelik ösyeterlik algisı ve tutumunun geometri dersi akademik. başarssm yordama güü̈ (Yayınlanmamış yüksek lisans tezi). Yıldız Teknik Üniversitesi, İstanbul.

Çakıroğlu, A. (2007a). Üstbiliş. Türkiye Sosyal Araștırmalar Dergisi, 2, 22-26.

Çakıroğlu, E. \& Işıksal, M. (2009). İlköğretim öğretmen adaylarının matematiğe yönelik tutum ve özyeterlik algilar1 [Preservice elementary teachers' attitudes and self-efficacy beliefs toward mathematics]. Eğgitim ve Bilim, 34(151), 132-139.

Çalışkan, M. \& Sünbül, A. M. (2010). Öğgrenme stratejileri ögrretiminin yürütü̈ü bilis bilgisine, yürütücü bilis becerilerini kullanmaya ve bașarya etkisi (Yayınlanmamıs doktora tezi). Selçuk Üniversitesi, Konya.

Çelik, E. (2012). Matematik problemi çöæme başarısı ile üstbilissel özdüzenleme, matematik özyeterlik ve özdeğerlendirme kararlarmmn doğruluğu arasındaki ilișkinin incelenmesi (Yayınlanmamış doktora tezi). Marmara Üniversitesi, İstanbul.

Çikrıkci, Ö. \& Odacı, H. (2013). Fen lisesi öğrencilerinin bilişötesi farkındalıkları ile öz yeterlik algılarının bazı kişisel ve akademik değişkenlere göre incelenmesi [Investigating science high school students' metacognitive awareness and self-efficacy perceptions with respect to the some individual and academic variables]. Journal of Human Sciences, 10(2), 246-259.

Demir, Ö. \& Özmen, S. K. (2011). Üniversite öğrencilerinin üst biliș düzeylerinin çeșitli değișkenler açısından incelenmesi. Cukurova Üniversitesi Sosyal Bilimler Enstitüsü Dergisi, 20(3), 145-160. 
Demircioğlu, H. (2008). Matematik ögrretmen adaylarmın üstbilissel davranıslarmın gelişimine yönelik tasarlanan eğitim durumlarmm etkililiği (Yayınlanmamış doktora tezi). Gazi Üniversitesi, Ankara.

Demirsöz, E.S. (2010). Yaratıcı dramanın ögretmen adaylarmın demokratik tutumlar, biliš̈̈stü farkındalıklar ve duygusal zekâa yeterliliklerine etkisi(Doktora Alunan tezi). yer http://acikerisim.deu.edu.tr/xmlui/handle/12345/6788

Dilci, T. \& Kaya, S. (2012). 4. ve 5. sınıflarda görev yapan sınıf öğretmenlerinin üstbilișsel farkındalık düzeylerinin çeşitli değişkenler açısından incelenmesi. Süleyman Demirel Üniversitesi Sosyal Bilimler Dergisi, 27, 247-267.

Duran, M. (2011). İlköğretim 7. sinf ögrencilerinin görsel matematik okuryazarlĭg özyeterlik algılar ile görsel matematik başarları arasındaki ilişki (Yayınlanmamış yüksek lisans tezi). Erzincan Üniversitesi, Erzincan.

Durdukoca, Ş. F. (2013). Dizgeli eğitim ve düz, anlatım yöntemleriyle isllenen ögretim uygulamalarmmn ögretmen adaylarmın epistemolojik inanç, ögrenme yaklașımlar, üstbilissel farkindalık ve akademik bașarlarna etkisi (Doktora tezi). Alınan yer http://openaccess.inonu.edu.tr:8080/xmlui/handle/11616/1344

Duru, M. K. (2007). İlköğretim fen bilgisi dersinde beyin firtınası ile ögretimin başarya, kavram ögrrenmeye ve biliş̈̈stü becerilere etkisi (Yayınlanmamıs doktora tezi). Marmara Üniversitesi, İstanbul.

Ekenel, E. (2005). Matematik dersi bașarısı ile bilișötesi öğrenme stratejilleri ve sinav kaygısının ilişkisi (Yayınlanmamış yüksek lisans tezi). Anadolu Üniversitesi, Eşkişehir.

Ektem, I.S. (2007). İlkögretim 5. simf matematik dersinde uygulanan yürütüiü bilis stratejïlerinin ögrenci erişi ve tutumlarna etkisi (Yayınlanmamıs doktora tezi). Selçuk Üniversitesi, Konya.

Erdoğan, A., Baloğlu, M. \& Kesici, Ş. (2011). Gender differences in geometry and mathematics achievement and self-efficacy beliefs in geometry. Eurasian Journal of Educational Research, 43, 188-205.

Gelen, I. (2003). Bilissel farkundallk stratejilerinin Türkşe dersine ilişkin tutum, okuduğunu anlama ve kaluculı̆ga etkisi (Yayınlanmamış doktora tezi). Çukurova Üniversitesi, Adana.

Goodwin, K. S., Ostrom, L. \& Scott, K. W. (2009). Gender differences in mathematics self-efficacy and back substitution in multiple-choice assessment. Journal of Adult Education, 38(1), 22.

Gülten, D. Ç. \& Soytürk, İ. (2013). İlköğretim 6. sınıf öğrencilerinin geometri öz-yeterliklerinin akademik başar1 not ortalamalar1 ile ilişkisi. Mehmet Akif Ersoy Üniversitesi Ë̆itim Fakültesi Dergisi, 1(25), 55-70.

Gündoğdu, S. (2013). 7. ve 8. sinf ögrencilerinin sabip olduğu matematiksel güc ile matematik özyeterliği arasindaki iliski (Yayınlanmamış yüksek lisans tezi). Eskişehir Osmangazi Üniversitesi, Eskişehir.

Işıksal, M. \& Așkar, P. (2003). İlköğretim öğrencileri için matematik ve bilgisayar öz-yeterlik alg1sı ölçekleri [ The scales of perceived mathematics and computer self-efficacy for elementary students]. Hacettepe Üniversitesi Ĕ̈itim Fakültesi Dergisi, 25(25), 109-118.

Kaplan, A., Duran, M. \& Baş, G. (2016). Examination with the structural equation modeling of the relationship between mathematical metacognition awareness with skill perception of problem solving of secondary school students. Journal of the Faculty of Education, 17(1), 01-16.

Karatay, H. (2010). İlköğretim öğrencilerinin okuduğunu kavrama ile ilgili bilişsel farkındalıkları. Türklük Bilimi Arastirmalar, 27(27), 457-475.

Kışkı1r, G. (2011). Öğretmen adaylarımn bilişötesi farkındalı düzeyleri ile problem çözme becerileri arasındakı ilişkinin incelenmesi (Yayımlanmamış yüksek lisans tezi). Atatürk Üniversitesi, Erzurum.

Kitsantas, A., Cheema, J. \& Ware, H. (2011). Mathematics achievement: the role of homework and selfefficacy beliefs, Journal of Advanced Academics, 22(2), 310-339.

Landine, J. \& Stewart, J. (1998). Relationship between metacognition, motivation, locus of control, selfefficacy, and academic achievement. Canadian Journal of Counselling, 32(3), 200-212.

Liliana, C. \& Lavinia, H. (2011). Gender differences in metacognitive skills. a study of the 8 th grade pupils in Romania. Procedia-Social and Behavioral Sciences, 29, 396-401.

Milli Eğitim Bakanlığ1 (2013). Ortaokul matematik dersi ögretim program ve kelavuðu. Alınan yer http://ttkb.meb.gov.tr/program2.aspx?islem $=1 \& \mathrm{kno}=215$

Melanlığlu, D. (2011). Üstbilis stratejileri eğitiminin ilkögretim ikinci kademe öğrencilerinin dinleme becerilerine etkisi (Yayınlanmamıs doktora tezi). Gazi Üniversitesi, Ankara.

Memnun, D. S. \& Akkaya, R. (2009). The levels of metacognitive awareness of primary teacher trainees. Procedia-Social and Behavioral Sciences, 1(1), 1919-1923.

Namlu, A. G. (2004). Bilişötesi Öğrenme Stratejileri Ölçme Aracının Geliştirilmesi: Geçerlik ve Güvenirlik Çalışması. Anadolu Üniversitesi Sosyal Bilimler Dergisi, 4(2), 123-136.

Olgun, A. (2006). Bilgisayar destekli fen bilgisi ögretiminin ögrencilerin fen bilgisi tutumlar, bilisüstü becerileri ve bașarlarna etkisi (Yayınlanmış yüksek lisans tezi). Eskişehir Osmangazi Üniversitesi, Eskişehir.

Özsoy, G. (2006, Nisan). Problem çözme ve üstbiliș. Ulusal Sınıf Öğretmenliği Kongresi’nde sunulan bildiri, Ankara.

Özsoy, G. (2007). Illköğretim beşinci simfta üstbilis stratejileri ögretiminin problem çözme başarısına etkisi (Doktora Tezi). 
Alınan yer http://www.acikarsiv.gazi.edu.tr/index.php?menu=2\&secim=10\&YayinBIK=175\#

Özsoy, G. \& Günindi, Y. (2011). Okulöncesi Öğretmen Adaylarının Üstbilişsel Farkındalık Düzeyleri. İlkëgretim Online, 10(2), 430-440.

Öztürk, Y.A \& Şahin, C.. (2015). Matematiğe ilişkin akademik başar1-özyeterlilik ve tutum arasındaki ilişkilerin belirlenmesi [ Determining the relationships between academic achievement, self-efficacy and attitudes towards maths]. International Journal of Social Science, 31, 343-366. doi:10.9761/JASSS2621.

Pajares, F. \& Miller, M. D. (1994). Role of self-efficacy and self-concept beliefs in mathematical problem solving: A path analysis. Journal of educational psychology, 86(2), 193.

Pajares, F. (2005). Gender differences in mathematics self-efficacy beliefs. Gender differences in mathematics: An integrative psychological approach, 294-315.

Pilten, P. \& Yener, D. (2010). Evaluation of metacognitive knowledge of 5th grade primary school students related to non-routine mathematical problems. Procedia-Social and Behavioral Sciences, 2(2), 1332-1337.

Pişkin, M. \& Durmuş, S. (2010, AY). Sınıf öğretmeni adaylarının matematiğe karşı öz-yeterlik algıları. e-Journal of New World Sciences Academy, 5(3), 1189-1196.

Reçber, S. (2011). An investigation of the relationship among the seventh grade students' mathematics self efficacy, mathematics anxiety, attitudes towards mathematics and mathematics achievement regarding gender and school type (Yayınlanmamış yüksek lisans tezi). Middle East Technical University, Ankara.

Saban, A. İ \& Saban, A. (2008). Sınıf Öğretmenliği Öğrencilerinin Bilişsel Farkındalıkları İle Güdülerinin Bazı Sosyo Demografik Değişkenlere Göre İncelenmesi. Ege Ë̆itim Dergisi, 9(1), 35-38.

Sapanc1, A. (2012). Öğretmen adaylarının epistemolojik inançları ile bilişüstü düzeylerinin akademik başarıyla ilişkisi [The relationship of student teachers' epistemological beliefs and metacognitive levels with their academic achievement]. Celal Bayar Üniversitesi Sosyal Bilimler Dergisi, 10(1), 311-331.

Saraç, S. (2010). İlköğretim beşinci sımf ögrrencilerinin üstbiliș düzeyleri, genel zękâ ve okuduğunu anlama düreyleri arasindaki ilişkinin incelenmesi (Yayınlanmamış doktora tezi). Marmara Üniversitesi, İstanbul.

Senemoğlu, S. (1998). Gelişim, Öğrenme ve Öğretim; Kuramdan Uygulamaya. Ankara: Özsen Matbaacılık.

Şengül, S. \& Gülbağcı, H. (2013). 7. ve 8. sınıf öğrencilerinin sayı hissi ile matematik öz yeterlikleri arasındaki ilişkinin incelenmesi. International Journal of Social Science, 6(4), 1049-1060.

Tella, A. (2011) An assessment of mathematics self - efficacy of secondary school students in Osun State, Nigeria, Ife Psychologza, 19(1), 430-440.

Temur, T., Kargin, T., Bayar, S. A. \& Bayar, V. (2010). Metacognitive awareness of grades 6, 7 and 8 students in reading process. Procedia-Social and Behavioral Sciences, 2(2), 4193-4199.

Terzi, M. \& Mirasyedioğlu, Ş. (2009). İlköğretim matematik öğretmen adaylarının matematiğe yönelik özyeterlik algılarının bazı değişkenler açısından incelenmesi. TÜBAV Bilim Dergisi, 2(2), 257-265.

Tok, H., Özgan, H. \& Döş, B. (2010). Uzaktan eğitim sıınıfında başarının pozitif yordayıcısı olarak bilişötesi farkındalık stratejisi ve öğrenme stratejilerinin değerlendirilmesi. Mustafa Kemal Üniversitesi Sosyal Bilimler Enstitüsü Dergisi, 7(14), 123-134.

Topçu, M. S. \& Tüzün, Ö.Y. (2009). İlköğretim öğrencilerinin biliş ötesi ve epistemolojik inançlarıly fen başarıları, cinsiyetleri ve sosyoekonomik durumları. Elementary Education Online, 8(3), 676-693.

Tunca, N. \& Alkın-Șahin, S. (2014). Öğretmen adaylarının bilișötesi (üst biliș) öğrenme stratejileri ile akademik Öz yeterlik inançları arasındaki ilişki [The relationship between pre-service teachers' metacognitive learning strategies and academic self-efficacy]. Ë̈itim Bilimleri Uluslararası Anadolu Dergisi, 4(1), 47-48. doi: 10.18039 /ajesi.89592.

Tuncer, T. (2011). Matematik dersi yedinci simf "permütasyon ve olasllk" konusunda uygulanan üstbilis stratejilerinin, ögrencilerin başarlarna, üstbilis becerilerine, tutumlarna ve kaluchlĭga etkisi (Yayınlanmamıs yüksek lisans tezi). Atatürk Üniversitesi, Erzurum.

Tüysüz, C., Karakuyu, Y. \& Bilgin, İ. (2008). Öğretmen adaylarının üst biliş düzeylerinin belirlenmesi. Abant İzæet Baysal Üniversitesi Sosyal Bilimler Enstitïsï Dergisi, 2(17), 147-158.

Umay, A. (2001). İlköğretim matematik öğretmenliği programının matematiğe karşı özyeterlik algısına etkisi [The effect of the primary school mathematics teaching program on the mathematics self-efficacy of students]. Journal of Qafqaz University, 8(1).

Ural, A. (2007). İsbirlikli ögrrenmenin matematikteki akademik başarya, kahcilŭga, matematike ösyeterlik algrsma ve matematiğe karşı tutuma etkisi (Yayınlanmamış doktora tezi). Gazi Üniversitesi, Ankara.

Ural, A., Umay, A. \& Argün, Z. (2008). Öğrenci takımları başarı bölümleri tekniği temelli eğitimin matematikte akademik başarı ve özyeterliğe etkisi [The effect of students teams-achievement divisions method based instruction on mathematics academic achievement and self-efficacy]. Hacettepe Üniversitesi Ĕ̈itim Fakültesi Dergisi, 35(35), 307-318.

Üredi, I. ve Üredi, L. (2005). İlköğretim 8. sınıf öğrencilerinin öz-düzenleme stratejileri ve motivasyonel inançlarının matematik başarısını yordama gücü. Mersin Üniversitesi Ë̆itim Fakültesi Dergisi, 1(2). 250-260. 
Yabaş, D. (2008). Farklılaştırılmış öğretim tasarımının öğrencilerin özyeterlik algıları, bilişüstü becerileri ve akademik başarılarına etkisinin incelenmesi (Yayınlanmamış yüksek lisans tezi). Yıldız Teknik Üniversitesi, İstanbul.

Yağmur, A. (2012). Anadolu ögrretmen liselerinde ögrenim gören ögrencilerin matematik dersine yönelik tutumlar ile özyeterlilikleri arasındaki ilişki (Yayınlanmamış yüksek lisans tezi). Ahi Evran Üniversitesi, Kırşehir.

Yenilmez, K. \& Kakmacı, Ö. (2008). İlköğretim matematik öğretmenliği bölümü öğrencilerinin öz yeterlilik inanç düzeyleri. Eskişehir Osmangazi Üniversitesi Sosyal Bilimler Dergisi, 9(2), 1-21.

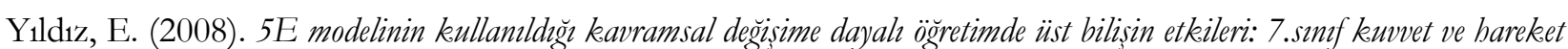
ünitesine yönelik bir uygulama (Doktora tezi). http://acikerisim.deu.edu.tr/xmlui/handle/12345/6859 adresinden erişilmiştir.

Yıldız, G. (2010). İlkögrretim 7. smmf ögrencilerinin matematik başarlar, bilişüstü stratejileri, düşünme stilleri ve matematik. öz kavramlar arasındaki ilişkiler (Yayınlanmamış doktora tezi). Yıldız Teknik Üniversitesi, İstanbul.

Yurdakul, B. (2004). Yapılandırmac ögrenme yaklaşımını ögrrenenlerin problem çö:əme becerilerine, bilisötesi farkındahk ve derse yönelik tutum düzeylerine etkisi ile ögrenme sürecine katkılar (Yayınlanmamış doktora tezi). Hacettepe Üniversitesi, Ankara.

\section{Citation Information}

Öztürk, B. \& Kurtuluş, A. (2017). Ortaokul Öğrencilerinin Üstbilişsel Farkındalık Düzeyi İle Matematik Öz Yeterlik Algısının Matematik Başarısına Etkisi. Dicle Üniversitesi Ziya Gökalp Eğitim Fakültesi Dergisi, 31, 762-778. 